\title{
Unemployment and job vacancies - theoretical model and empirical analysis for Bulgaria.
}

\author{
Svetlana Ivanova Todorova ${ }^{1}$ \\ 1 - Technical University of Varna, Department of Social and Legal Sciences, 9010, 1 Studentska Street, Varna, Bulgaria \\ Corresponding author contact: si.todorovalabv.bg
}

\begin{abstract}
The unemployment and the issues relating to it refer to the entire population of a given country and that's why they are always relevant. The present article examines the main factors exerting a powerful effect on the unemployment level - the active labour market policy, the labour mobility, the labour productivity and the labor force level. Developed is a theoretical model on the basis of which an empirical analysis is made of the data reflecting the unemployment level in the country over the 2013-2018 period. A special attention is paid to the mutual relation between the unemployment level and the number of the job vacancies, and it is precisely this interdependence that _is examined and analysed in the paper using the Beveridge curve.
\end{abstract}

Keywords: unemployment, free workplaces, Beveridge curve, labor mobility

\section{INTRODUCTION}

The employment and the unemployment-related problems are now extremely live. Every day measures to limit unemployment and promote the employment are constantly sought for and applied in our society. These two components of the labour market predetermine to a large extent the government policy content in the area of the labour market, and also reveal parts of the "social and economic prosperity in a national and international aspect" (Тодоров, 2012) of the respective country.

During the period of economic and social system transformation in our country, which started in the beginning of the 90's of the 20th century, together with the revision of the basic economic and social relations, the governmental policy regarding the issues of employment and unemployment has gradually changed. In the first years of transition our country adhered to a more passive employment policy. The passive employment policy accentuates mainly "the help, the social insurance and the assistance for unemployed people during the period when they are not registered at the Labour office". (Владимирова, 1995) It can be said that this type of employment policy does not stimulate sufficiently the unemployed persons to pass to the economically active population because of the fact that the financial assistance provided by the state as an unemployment benefit is sufficient to satisfy the current needs and necessities, but as a rule, this benefit cannot stimulate the person to start sooner the process of searching for a new employment. The passive employment policy is implemented mainly through the Unemployment Fund. An active policy is the policy whose measures are directed to stimulating the labour market and creating additional opportunities so that the working-age population to fall in the real labour scope. This policy has impact both on employers and employees and is aimed to expand the employment areas and retrospectively to decrease or restructure the unemployment. The active policy of promoting the employment and limitation of the unemployment is in its larger part purely economic and its results depend on the government's ability to implement it. (Петров, 2014) The main part of the actual employment policy is opening additional job positions through governmental programs and other programs for subsidized employment. (Андреева, 2014) Openingof job positions under a certain program is only a temporary solution to the employment-related issues. 


\section{MAIN TEXT}

\section{Mutual relationship between the unemployment and the job vacancies. Beveridge curve}

\subsection{Mutual relationship between the unemployment level and the number of job vacancies}

The Beveridge curve depicts graphically the interrelated dependency between the unemployment and the number of the job vacancies. The curve is named after the English economist Lord William Beveridge, who was the first to present this dependency. He also became well-known for his work "Social Insurance and Allied Services", also popular as "the Beveridge report", written during the WW2 in 1942 and outlining the construction of the modern common welfare country (Мавров, 2007). The curve is one of the main instruments to measure the structural unemployment and represent the dependency between the unemployment level and the number of job vacancies. With high level of unemployment the number of job seekers increases, compared to a period with normal unemployment levels, which leads to faster occupying of job vacancies. There are states of the labour market, when the unemployment level rises together with the number of the job vacancies, or the unemployment level decreases, but the number of job vacancies increases. (Дулевски, 2010) That kind of state is an indicator for structural problems in the labour market. (INFOSTAT)

The Beveridge curve is also known with the name U-V curve, since the unemployment is indicated with $\mathrm{U}$, and the job vacancies are indicated with $\mathrm{V}$. As a graphical expression usually the unemployment is located on the horizontal (abscise) axis, and the job vacancies on the vertical (ordinate) axis. Analytically, it is represented with the expression:

Where:

$$
U n=f(V n)
$$

- Un - an unemployed rate;

- $\quad \mathrm{Vn}-\mathrm{a}$ job vacancies rate.

Presented in Figure 1 - is a clear illustration of the Beveridge curve.

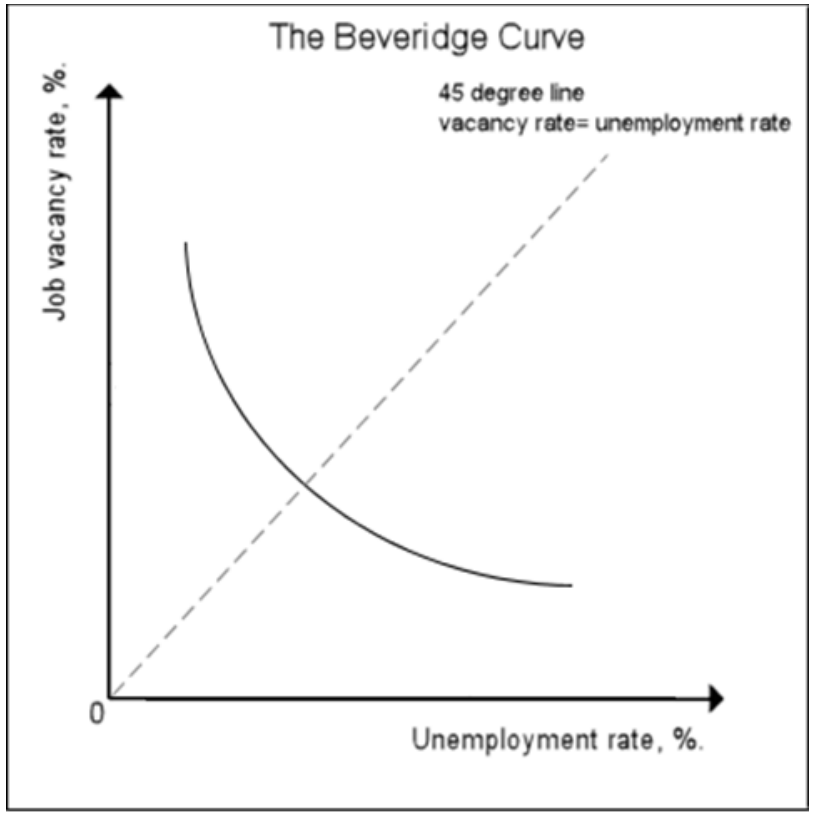

Figure 1 General graphical representation of the Beveridge curve (Source: en.wikipedia.org) 
The indicated curve dynamics is a concreate manifestation of the state of the economy. When the curve is in condition in which in its lower end the unemployment rate rises and the rate (number) of the job vacancies decreases, it shows a drop in the economic activity, and when its upper curve end the unemployment rate ${ }^{1}$ decreases and the job vacancies rate increases, it indicates a rise in the economic activity (economic growth). The natural unemployment level is between these two conditions of the Beveridge curve. (Мавров, 2007) The position of the curve itself on the coordinate axis is also an indicator for the state of the labour market. If it is shifted "to the right", this is taken as an indication of higher unemployment levels and greater number of job vacancies, which is an indication for structural problems in the labour market. Altermatively, when the curve shifts "to the left", the lower unemployment levels correspond to diminished number of job vacancies, which, in turn, is an indicator for an increase in the economic activity.

\subsection{Unemployment in Bulgaria}

The unemployment is one of the main components related to the Beveridge curve. Unemployed individuals in Bulgaria are considered all individuals within the age bracket between 15 and 74, who are jobless within the monitored period and at the same time actively seeking employment within the specified four-week period, including the monitored week, and are available to start work within two weeks until the end of the monitored period. (Statistical directory, 2019) The unemployment rate amongst the individuals aged 15-74 in Bulgaria in December 2018 (according to EUROSTAT data, compared to the data from the member-states of the European Union) was 5.2\% or a total of 173.3 thousand individuals, with an average of $6.6 \%$ for the European Union (EU 28) and 7.9\% for the Eurozone (EU 19).

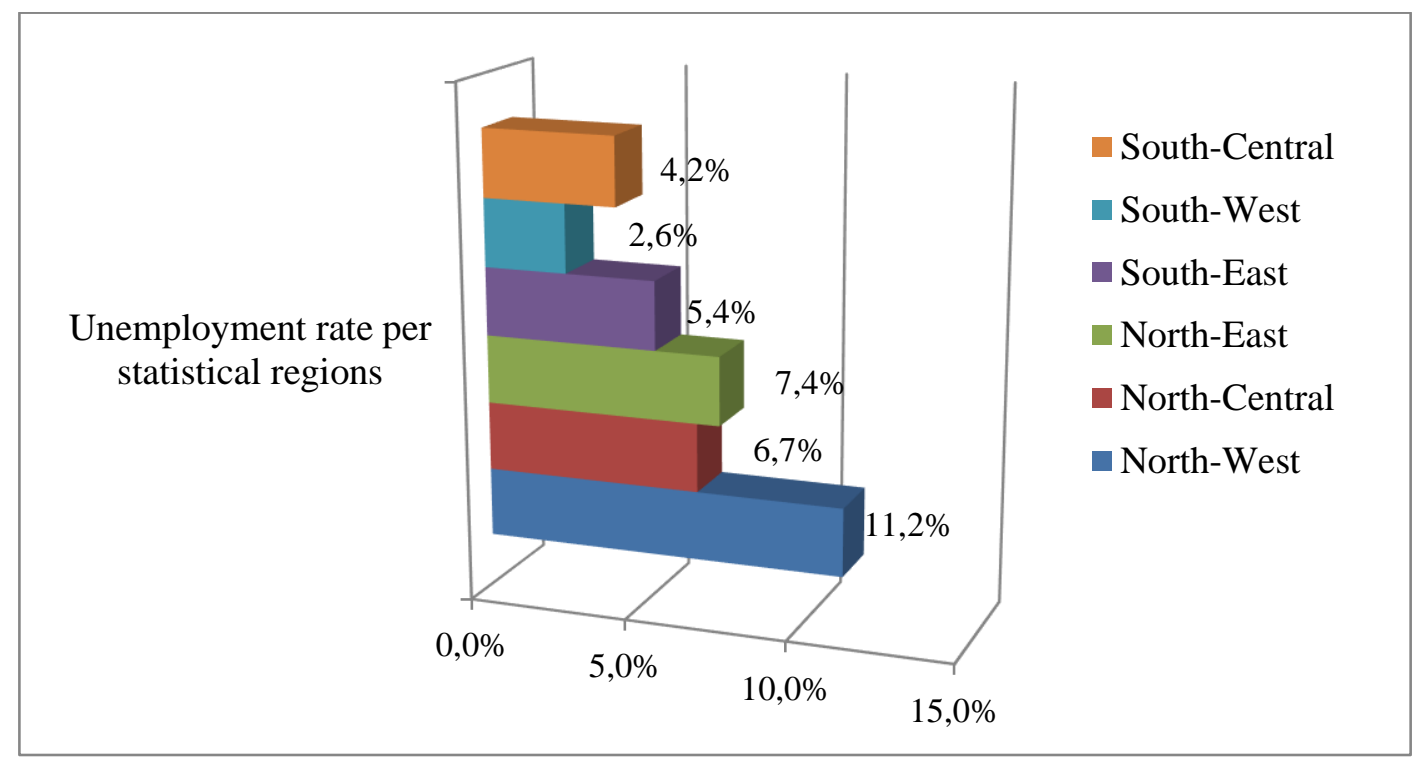

Figure 2 Unemployment rate in Bulgaria per statistical regions. (Source: National Statistic Institute, 2018)

According to the Figure 2 data we can determine that in our country we observe big regional differences in terms of the employment. Thus, for example, as a result of intemal labour migration, the highest unemployment rate is observed in the North-West region $-11.2 \%$, while the lowest one - in the

\footnotetext{
${ }^{1}$ According to Infograph data, unemployed are individuals aged 15-74, who do not work, but are actively seeking for job and are available to start work within two weeks from the end of the monitored period. The unemployment rate is measured in percents $(\%)$ and represents the share of the unemployed people as a part of the workforce. For example, in 2013 in Bulgaria, with 433.2 thousand unemployed individuals aged 15-64 and workforce of 3322.7 thousand individuals, the unemployment rate was $13.0 \%$. UR $=(433.2 / 3322.7) * 100=13.0$.
} 
South-West region $-2.6 \%$. There is a continuous influx of the economically active population in working age from the small towns and villages and from the smaller districts to the big district cities and the capital. From that perspective, districts such as Vidin, Montana and Shumen have an unemployment rate almost twice higher than the rate for the country, and the districts near Sofia have an unemployment rate twice lower than the rate for the country.

Presented in Figure 3 is a more detailed description about the gap in the unemployment rate in 2018 by districts.

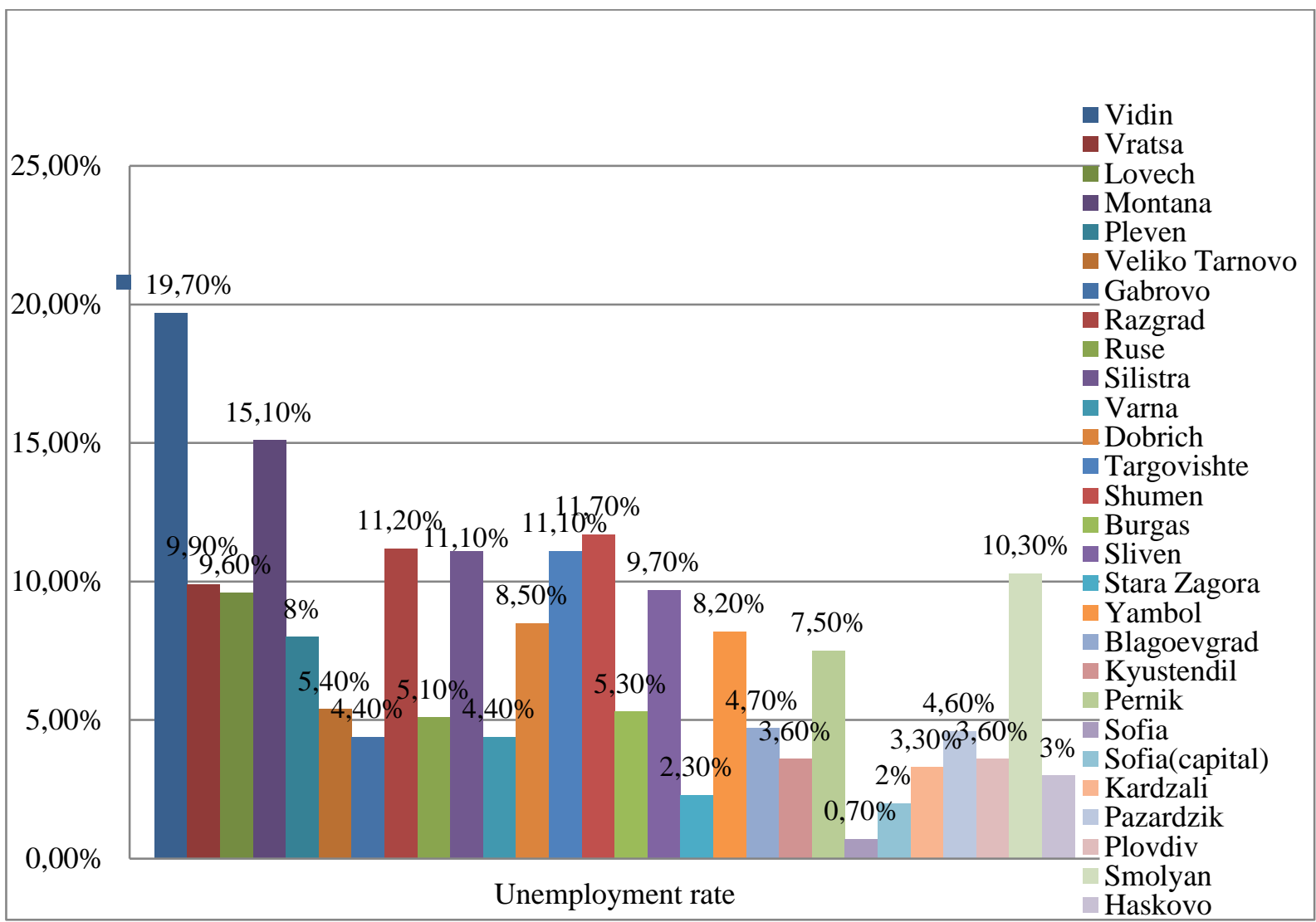

Figure 3 Unemployment rate in Bulgaria in 2018 -a regional cross-section view per districts (Source: National Statistic Institute, 2018)

Considering the data presented it is obvious that the highest unemployment rate for 2018 was registered in the district of Vidin - 19.7\%, followed by the district of Montana with $15.1 \%$, and Shumen with $11.7 \%$. The lowest unemployment rate is registered in the city of Sofia and the district of Sofia with $0.7 \%$ and $2 \%$, respectively, followed closely by Stara Zagora with its $2.3 \%$.

Accordingly, it all points to the conclusion that the unemployment rate in Bulgaria for 2018 by districts is significantly higher than the average for the country -7 out of the 28 district cities have unemployment rate above $10 \%$, and the average unemployment rate by districts is $7.28 \%$, which also exceeds the unemployment rate for the country in 2018 (5.2\%).

In comparison, the National Statistic Institute data for 2017 show that the unemployment rate for the country is $6.2 \%$, and the data for the last quarter of 2019 show that the unemployment rate for the country is $3.7 \%$, or the total number of the unemployed individuals is 125.4 thousand. All this shows a trend to its decrease.

The other component of the Beveridge curve is the job vacancies and in particular, the job vacancies rate. According to the National Statistic Institute a job vacancy means: "a newly created, unoccupied position or position that will be vacant, for which two conditions are met: 1) the employer takes active steps to find a suitable candidate outside the enterprise and is ready to take new ones; 2) the employer intends to fill the vacant position immediately or in near future. "Active steps" means announcing the job position as vacant in the labour offices; publishing advertisements in newspapers, internet, TV; 
announcing recruitment competitions; making direct contact with potential candidates. "Near future" means a 3-month period." (Eurostat) The job vacancies rate is calculated by dividing the job vacancies to the amount of job vacancies and the occupied job positions and the result is multiplied by 100 . The job vacancies rate is part of the short-term statistics regarding the state of the labour market, which is officially published by the National Statistic Institute and is calculated both in total for the economy, and for the individual economic activities. (Infograph)

Table 1 provides data about the calculated values for the country as a whole during the analysed 2014-2018 period. The annual job vacancies rate values are calculatedfot the purposes of the present paper on the basis of the official data about the number of the vacant and the number of the occupied job positions per quarters for the examined 2014-2018 period.

\begin{tabular}{|c|c|c|c|}
\hline № & Year & Unemployment rate & Job vacancies rate \\
\hline 1 & 2014 & 11,5 & 0,7 \\
\hline 2 & 2015 & 9,2 & 0,8 \\
\hline 3 & 2016 & 7,7 & 0,9 \\
\hline 4 & 2017 & 6,2 & 0,8 \\
\hline 5 & 2018 & 5,3 & 0,9 \\
\hline
\end{tabular}

Table 1 Unemployment and job vacancies rates during the 2014-2018 period for the Republic of Bulgaria (Source: Infostat)

Using the data in Table 1 we can draw a graph of the Beveridge curve for the analysed period. Figure 4 shows the specified curve for the 2014-2018 period.

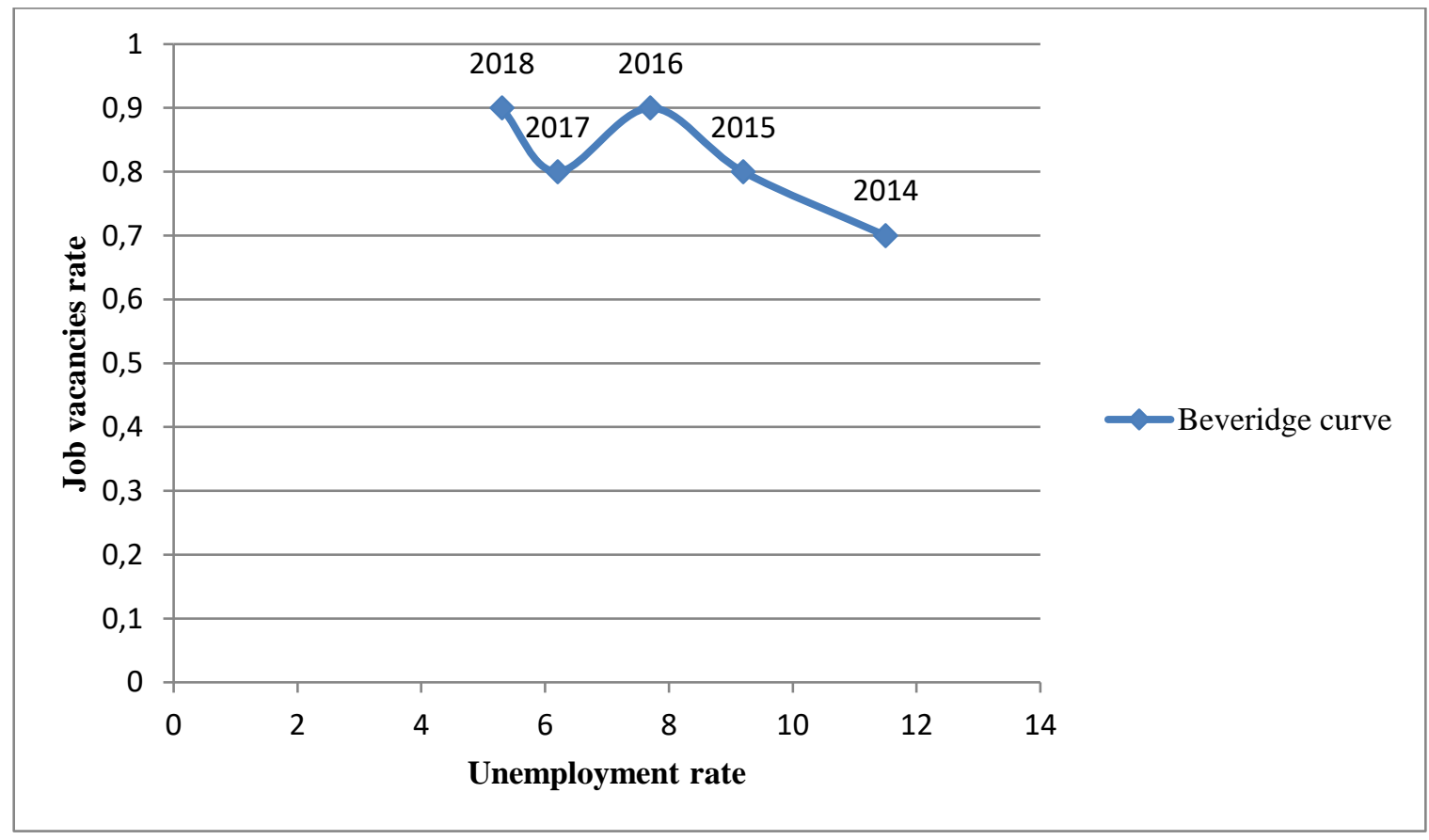

Figure 4 Beveridge curve during the 2014-2018 period for the Republic of Bulgaria

Based on the graphics, presented in Figure 4, the following conclusions can be drawn. Within the indicated period, outlined can be 3 distinctly different phases of development of the Beveridge curve:

- First phase - comprises the 2014-2016 period. During that period, as can be seen from the graphics, perceived is an upward curve trend, whereas the unemployment rate decreases significantly from 11.5 (2014) to 7.7 (2016), which leads to a small increase of the job vacancies rate from 0.7 (2014) to 0.9 (2016). In this segment the Beveridge curve registers an oblique rising and is situated in the right-side part of the scale; 
- Second phase - refers to the 2016-2017 period. A distinguishing feature of that period is the downward curve trend, in which the unemployment rate decreases relatively sharply from 7.7 (2016) to 6.2 (2017), which corresponds to a relatively weak decrease in job vacancies rate by 0.1 (from 0.9 for 2016 to 0.8 for 2017). In this segment the Beveridge curve registers a steeper decrease and a slight shift to the left scale part;

- Third phase - it refers to the period 2017-2018. Here, as illustrated in the graphics, there is a change in the trend from descending pattern into an ascending one, but with bigger curve declivity compared to the 2014-2016 period, when we had an ascending trend. The unemployment rate keeps on decreasing from 6.2 (2017) to 5.3 (2018), and job vacancies rate increases relatively weakly (with 0.1). Again, a weak shift of the curve occurs towards the left-side of the scale.

It is important also to indicate the reasons for leaving the job and entering the "unemployed" category. Figure 5 contains data regarding the percent distribution of the reasons for leaving jobs. According to the National Statistic Institute data 43.9 thousand of 173.3 thousand unemployed individuals for 2018 left their job because of position elimination or dismissal. Similar is the number of the individuals, who terminated their labour activity because of end of temporary or seasonal work - 44 thousand persons; 15.3 thousand leave by way of dissatisfaction with their working conditions, 7.7 thousand for personal reasons, and 7.5 thousand for other reasons. 24 thousand have not stated a reason, but this column also includes individuals, who have not worked during the last 8 years. 31 thousand is the number of individuals looking for their first employment, whereas 16.8 thousand of them look for a job after graduating from school or university.

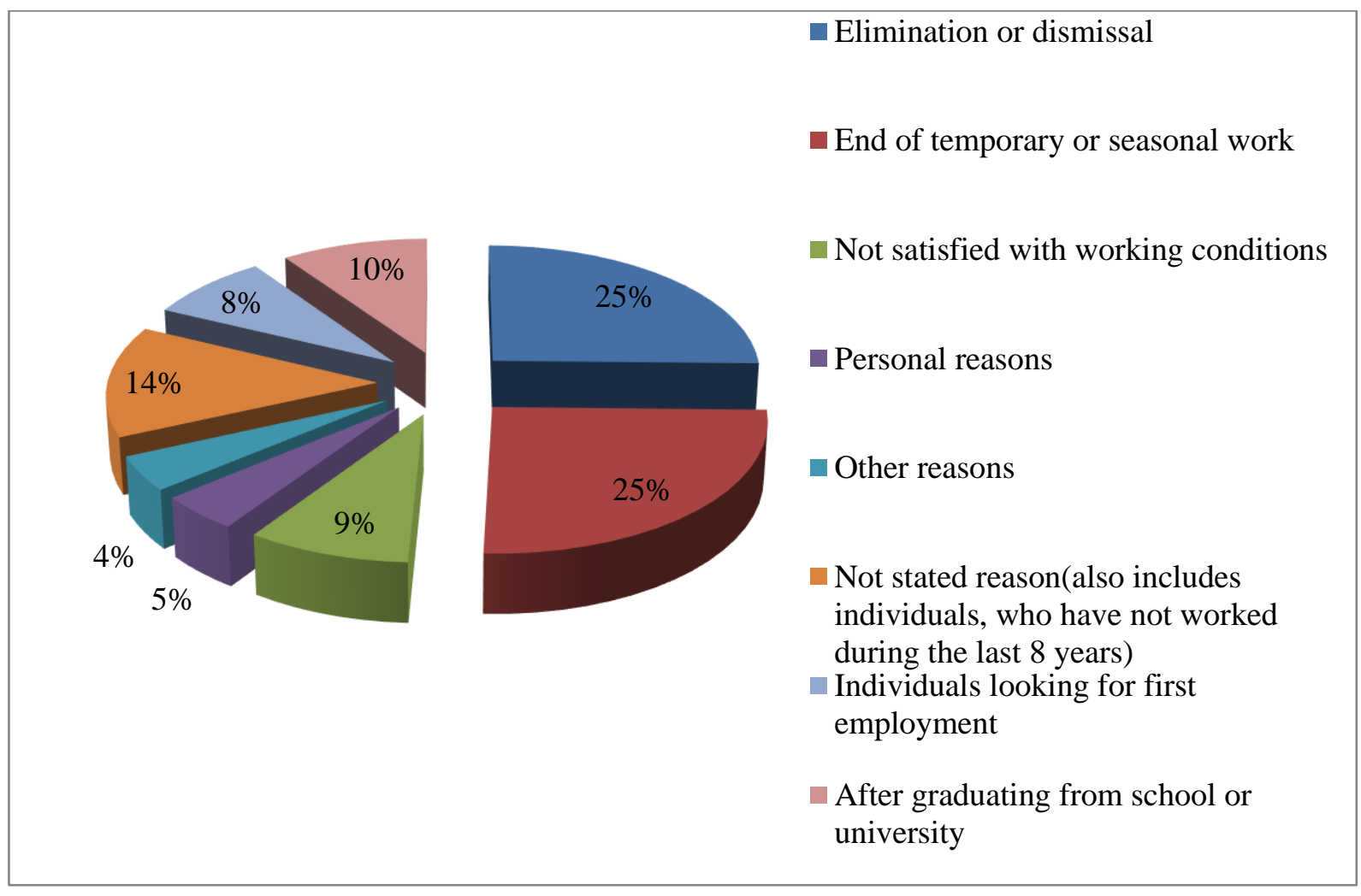

Figure 5 Reasons for leaving a job (2018) (Source: National Statistic Institute, 2018)

\section{Factors, influencing the unemployment in Bulgaria}

\subsection{Active labour market policy}

There are many factors that have influence on the unemployment in Bulgaria. The present paper, though, gives a sharper focus on the most significant of them, which are also typical of our country. 
Extensively discussed, so far, were the types of changes in economy in terms of the employment occurring in Bulgaria from the early 90s of the 20th century, and now we shall examine the main characteristics of the active labour market policy. The main goal of the active employment policies is to increase possibilities for work of job seekers and to improve the correspondence between the job vacancies and the unemployed individuals. (Атанасова \& Владимирова, 2011) The active labour market policy is broad and appears in many forms - creating new job positions, development of qualification and requalification programs for the unemployed and the employees, employee training programs. The main goal of the active labour market policies is to guarantee the soonest possible return of the unemployed persons to the employee group. Through the qualification and re-qualification programs a number of economy-related problems can be solved by helping the individuals in their choice of profession and acquiring the necessary skills for it. The active labour market policy is directed to all unemployed persons as a whole, but more specific attention has to be paid to the continuously unemployed persons, because of the fact that they represent the most vulnerable part of the labour market. The continuously unemployed persons lose their professional capacity, as well as their motivation to find a job. The possibility to get out of the unemployment status decreases with the increase of the unemployment duration, which leads to a bigger possibility for the individuals to remain jobless. (European Semester) Continuous stay of a single person in the group of the long-time unemployed hides a big risk after some time this person to get eventually into the group of "discouraged persons". Figure 6 shows the duration of the unemployment in Bulgaria for 2018 according to the National Statistic Institute data.

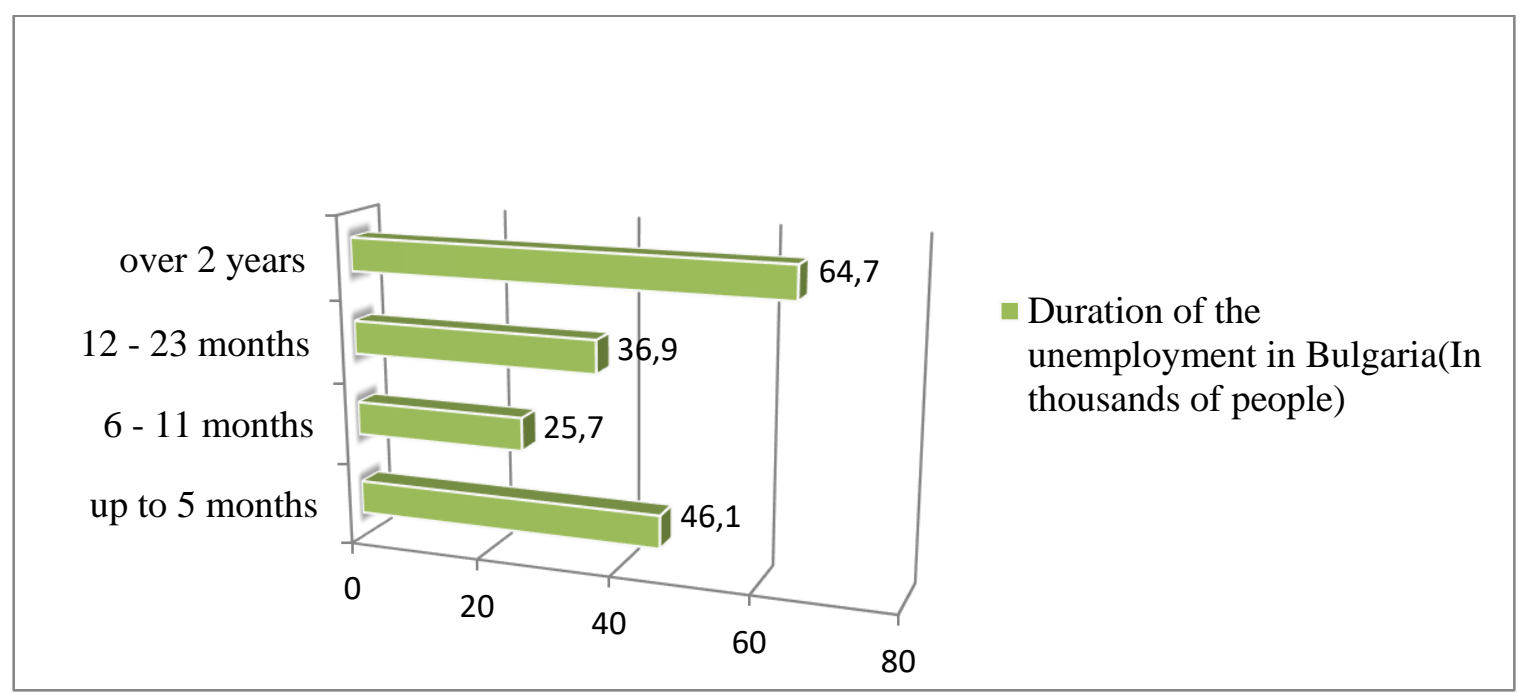

Figure 6 Duration of the unemployment in Bulgaria for 2018 (Source: National Statistic Institute, 2018)

The data stated for 2018 shows that the longest duration of the unemployment in Bulgaria is more than 2 years - nearly 65 thousand of a total of 173 thousand unemployed, or $37 \%$, have been unemployed for 2 or more years.

The continuous unemployment rate represents a relative share of the continuously unemployed persons from the economically active population. According to the data reported in Figure 5 the number of continuously unemployed persons ${ }^{2}$ in Bulgaria for 2018 (unemployed persons for a period of 12-23 months and more than 2 years) is 36.9 thousand individuals and 64.7 thousand individuals. The figures in Figure 6 indicate that the continuous unemployment rate for 2018 can be calculated by the following formula:

The number of continuously unemployed persons for $2018=36,9+64,7=101,6$ thousand persons

Economically active population $=$ total number of employed + total number of unemployed persons

Or $3152,7+173,3=3326$ thousand persons

From there we can calculate the continuous unemployment rate (Cur) as follows: 


$$
\begin{aligned}
& \text { Cur }=\frac{\text { continuously unemployed persons }}{\text { economically active population }} * 100 \\
& \text { Cur }=\frac{101,6 \text { thousand persons }}{3326 \text { thousand persons }} * 100=3,1 \%
\end{aligned}
$$

The persons above 15 years of age, who wish to work, but do not look for a job, because they think they will not find a job, are discouraged (Infograph). Also called "inactive workforce" (Дончева, 2009) For 2018, these people are a total of 85.4 thousand, and 81.4 of them are within the age group 15-64, as 12.7 thousand are 15-24 years of age, 16.3 thousand are 25-34 years of age, 19.3 thousand are 35-44 years of age, 14.8 thousand are 45-54 years of age, and 22.3 thousand are above 55 years of age. Presented in percentage this data appears as follows (Figure 7):

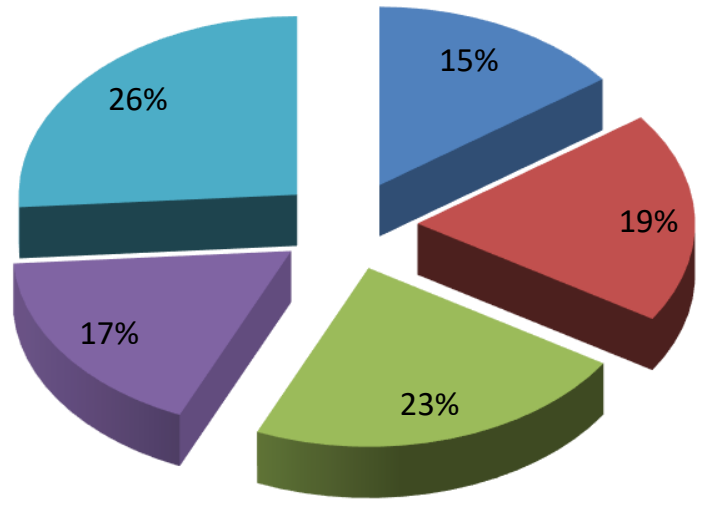

15-24 years

- 25-34 years

35-44 years

45-54 years

over 55 years

Figure 7 Discouraged persons in Bulgaria for 2018 classified by age (Source: National Statistic Institute, 2018)

All data and results outlined above indicate that the country needs the active labour market policy to prevail over the passive policy, as long as it is capable of solving the unemployment-related problems to a larger extent in the longer term. And it is for that reason precisely that the State Budget of the Republic of Bulgaria Act provides funds, on a yearly basis, for measures and programs under the active employment policy, adopted by the Council of Ministers. Persuant to the State Budget of the Republic of Bulgaria Act the funding of the active employment policy is provided on the basis of applications approved by the Ministry of Labour and Social Policy, and subject to the terms and conditions set forth by the Regulations of Implementation of this Act. (Law on the State Budget of the Republic of Bulgaria for 2018) In line with the Employment Promotion Act the funds for active policy should be spent for:

- Programs and measures for training adults and for vocational training;

- $\quad$ Programs and measures for maintaining and promoting employment;

- $\quad$ Programs and measures for encouraging the unemployed persons to become self-employed;

- $\quad$ Protection of the domestic labour market and implementation of international work force exchange contracts, under which the Republic of Bulgaria is a party, etc. (Employment Promotion Act)

In order to implement the active employment policy the Ministry of Labour and Social Policy, once a years, submits - to the Ministry of Finances the relevant accounts for the financial support by the State Budget of the Republic of Bulgaria Act.

According to the report on implementation of the state budget of the Republic of Bulgaria for 2018, the funds spent for implementation of the active employment policy amount to 79.1 million BGN, out of which 51.3 million BGN are accounted for as expenses, and 27.8 billion BGN represent transfers to ministries, departments and municipalities. With the accounts under the 2018 State Budget of the Republic of Bulgaria Act provided in the municipal budgets in Section "Programs, activities and services of social insurance, assistance and employment" are 338.3 million BGN. The implementation is 495.2 million BGN (8.4 million BGN of which represent capital costs), which makes $146.4 \%$ in relation to the Plan. The expenses under this section are intended to cover the activities on the social assistance and 
employment. The excess of the expenses compared to those foreseen in the law for 2018 is due to the transfers provided to the municipalities by the Ministry of Labour and Social Policy for payment of the remunerations of the employees under the temporary employment programs, and the funds provided by the central budget for payment by the State of allowances and compensations for free of charge or discounted travels of certain categories of eligible individuals, as well as social expenses made by decisions of the municipal councils. (Report on the Report on the Implementation of the State Budget of the Republic of Bulgaria for 2018)

\subsection{Labour mobility. Barriers to labour mobility}

Each single labour market has its own typical barriers on labour mobility. This determines its degree of flexibility, which in turn is related to the unemployment and the efficiency of the economic activities in the country - the more flexible labour market is characterised by lower unemployment and higher employment. One of the barriers, related to the labour mobility, is the geographical mobility of the labour - internal and international;

The internal mobility or internal migration increases the labour market flexibility and has a positive impact on the natural level of unemployment. (Мавров, 2007) The higher trend of the population to internal migration facilitates the achievement of the right a balance between the labor demand and supply.

Figure 8 shows the Infostat data for 2018, relating to the mechanical growth of some districts in Bulgaria.

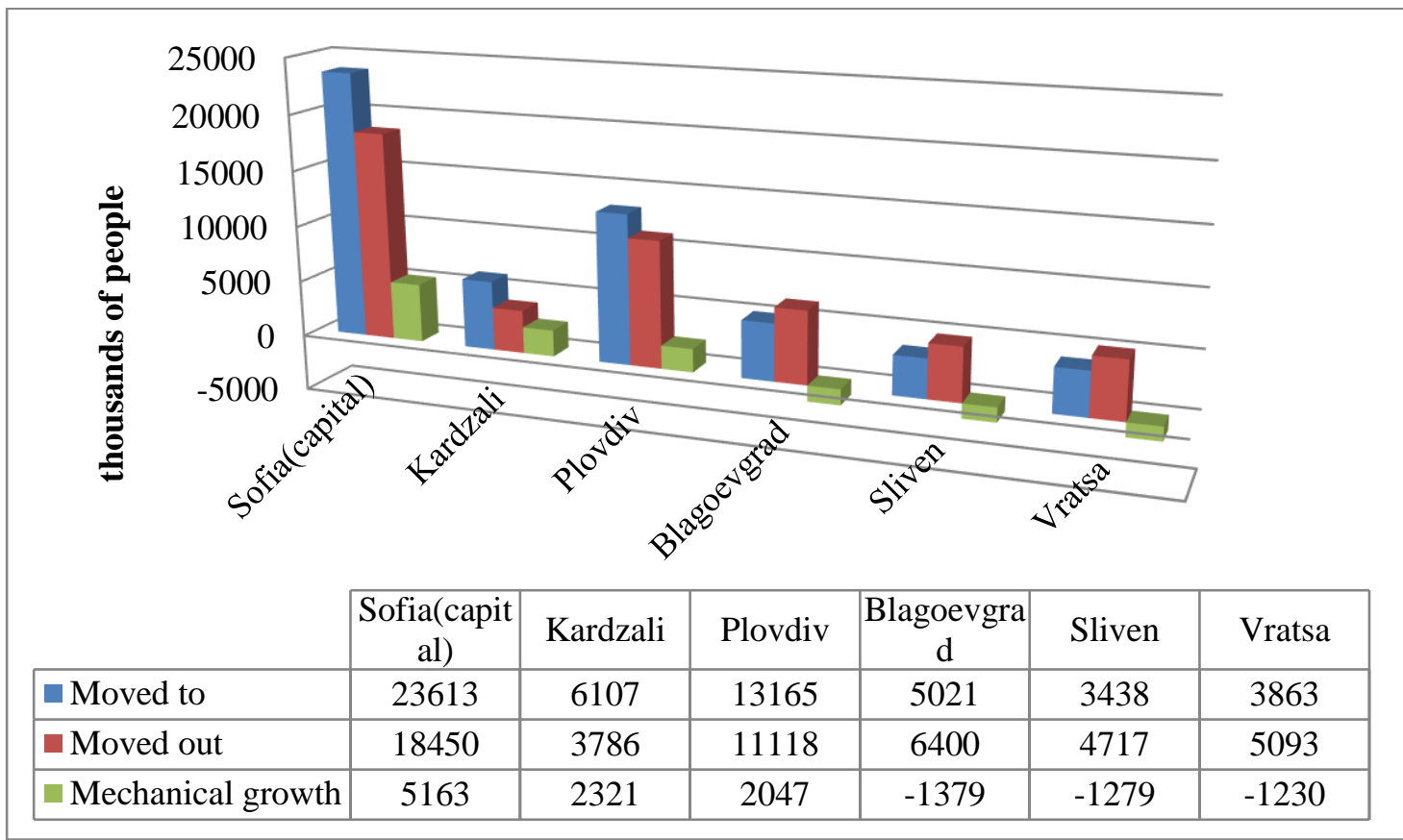

Figure 8 Mechanical growth of some districts in Bulgaria for 2018 (Source: Infostat, 2018)

The data shown indicate that Sofia (the capital city) has the largest mechanical growth relating to the number of those, who moved to and moved out of a given district, respectively -5163 persons, followed by the city of Kardzhali with 2321 persons, and the city of Plovdiv with 2047 persons. The largest negative mechanical growth has the city of Blagoevgrad -1379 persons, the city of Sliven with -1279 persons and the city of Vratsa with - 1230 persons, respectively. 
The mechanical movement of the population is related to a number of reasons. Unfortunately, the latest official data published by the National Statistic Institute is for the year 2013, and show the following characteristics (Figure 9) ${ }^{3}$

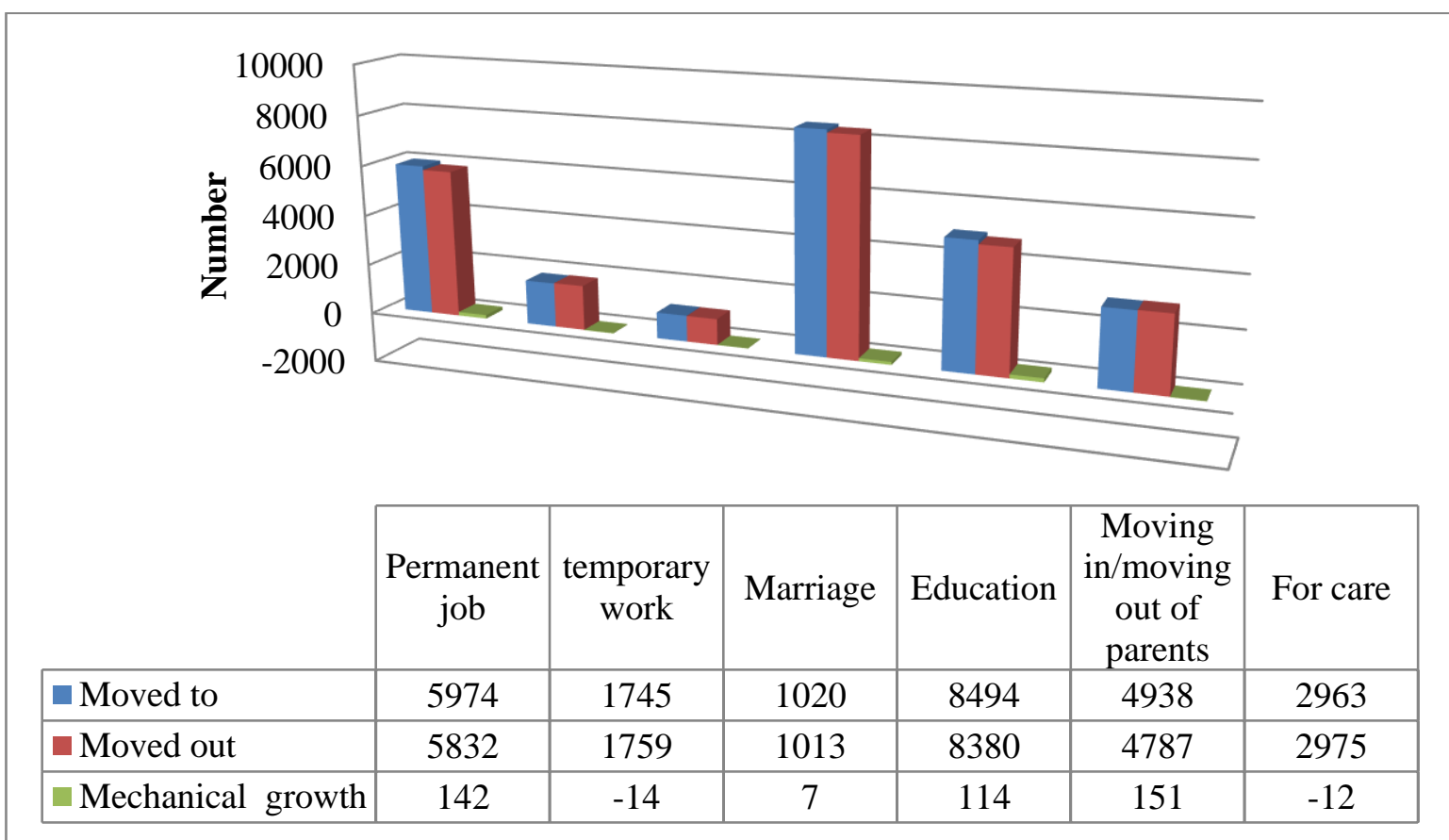

Figure 9 Mechanical movement of the population for 2013 classified by reasons (Source: National Statistic In-

The data in Figure 9 indicates the following: stitute, 2013)

- the total mechanical growth for our country for 2013 was negative -1108 individuals, which shows that more people moved out and less people moved in;

- $\quad$ In Figure 9, "Other" and "Not indicated" reasons are not indicated with a respective mechanical growth of 1177 and -2673 for our country;

- the major reason which causes either internal or international migration of our population for 2013 was the education: 8494 individuals moved in and 8380 individuals moved out - mechanical growth of 114 ;

- the biggest growth is due to the migration related to moving in or moving out of parents house: 151.

The home ownership rate has a great impact on the labour mobility. It turns out that our country has a very high percentage of home ownership, which represents a barrier to the mobility. According to Infostat data for 2018 the total number of homes is 3959285 , and twice as many homes are situated in cities and towns - 2634151 , and 1325134 in villages, and the prevalent part of them are owned by the city residents.

For example, owning a home in a region with lower economic activity stops labour migration to districts with higher economic activity and more job positions. Thus, people prove to be attached to their homes, since the selling prices of the real estates in the different districts are quite different - for example, a three-room flat in the city of Targovishte is sold at half the price of a three-room flat in the city of Varna.

The international migration includes two components - immigration or settling in the country, and emigration or leaving the country. The difference between those, who have immigrated and those, who have emigrated from the country indicates the mechanical growth of the population. The migration of the population has influence on the flexibility and the natural rate of unemployment because of the fact

\footnotetext{
${ }^{3}$ As from 2007, the mechanical movement of the population, reported by the National Statistic Institute includes not only the internal migration, but also the movement of individuals from and to the country (international migration)
} 
that usually highly qualified specialists leave our country and decide to emigrate in more developed European countries.(Ракаджийска, 2010) The data in Figure 10 refers to the level of the international migration in 2018 according to the age of the individuals, who have stated before the administrative authorities a change in their current address of residence from Bulgaria to a residence abroad and from abroad to Bulgaria.

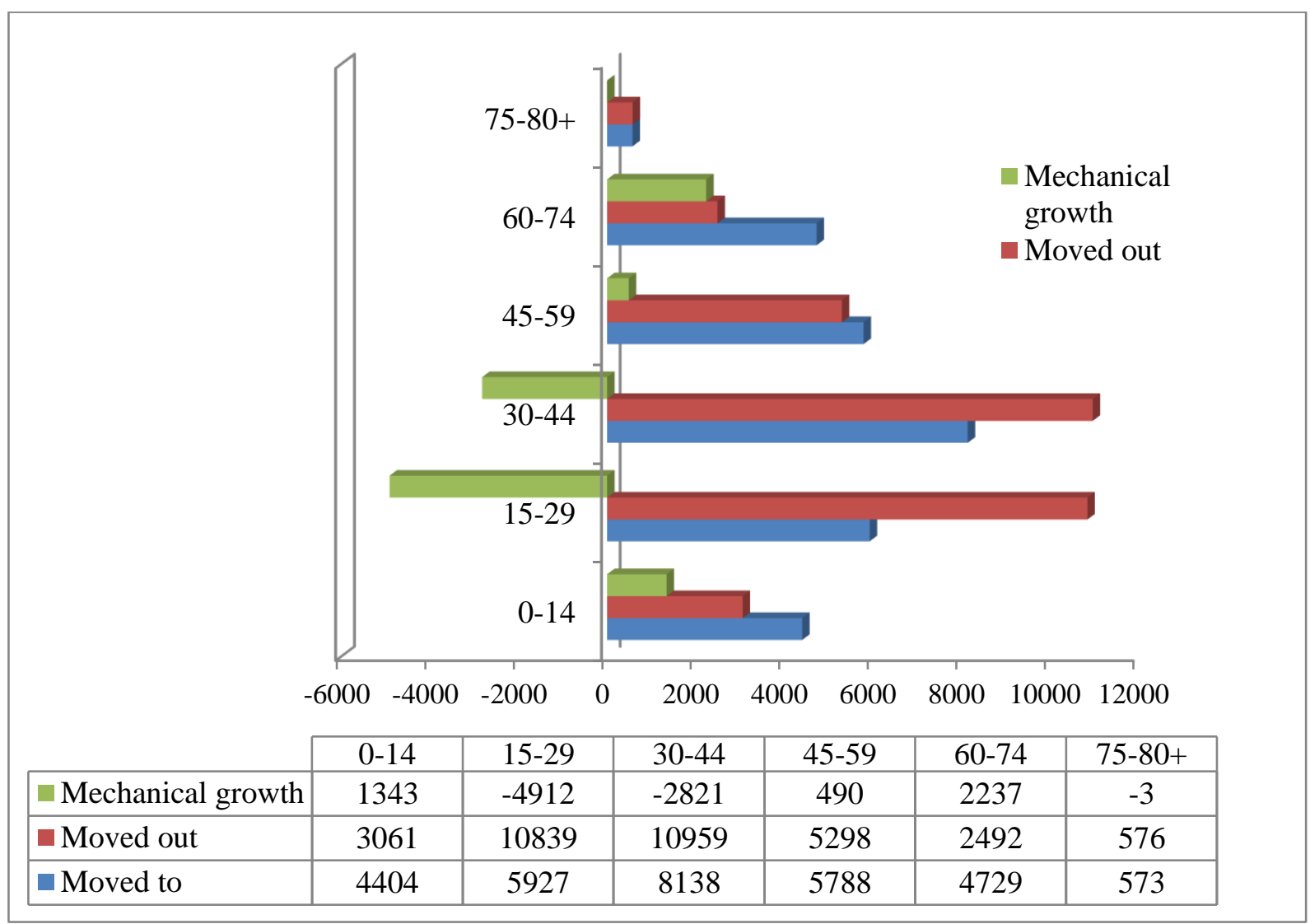

Figure 10 International migration in Bulgaria in 2018 by age (Source: Infostat, 2018)

The data in Figure 10 indicates a negative trend that the most active group of the population in working age of 15-44 years old leave the country. Usually these are qualified and quickly adapting people. Within the age groups of 15-29 and 30-44 there is a negative mechanical growth, which has a negative impact on the labour market flexibility, as well as on the natural rate of unemployment, because the highest mechanical growth is observed at the age group of 60-74, who are going out or have already gone out of the actively working population group.

The Infostat data in Figure 8 reveals the total number of those, who have settled in our country in 2018 as approaching 29559 individuals, and the number of those, who have left the country, as 33225 , which leads to a negative mechanic growth, equal to -3666 persons. Maybe this level is higher, because these data include only individuals, who have declared to the administrative authorities the change in their current address of residence from the country to a residence abroad and vice versa.

\subsection{Labour productivity}

The labour productivity represents the amount of the goods or services, created by an unit of labour. The labour productivity is an economic index, relating to the organization of the manufacturing process, the entrepreneurship and the innovations, and the skills and competence of the employees, and is represented by the following dependency:

Where:

$$
P L=\frac{Q}{H R}
$$

- PL - labour productivity:

- $\quad$ Q - amount of goods or services, manufactured for a given period; 
- $\quad$ HR - human resources, used to create Q.

The labour productivity is a composite economic index, which reflects the ability of the human labour to turn into a volume of production, manufactured for a certain time. Production activity is used to measure the gross domestic product (GDP) of the country, which provides valuable information about the national income and the total volume of the output products. The labour productivity dynamics in Bulgaria for the 2014-2018 period is shown in Figure 11.

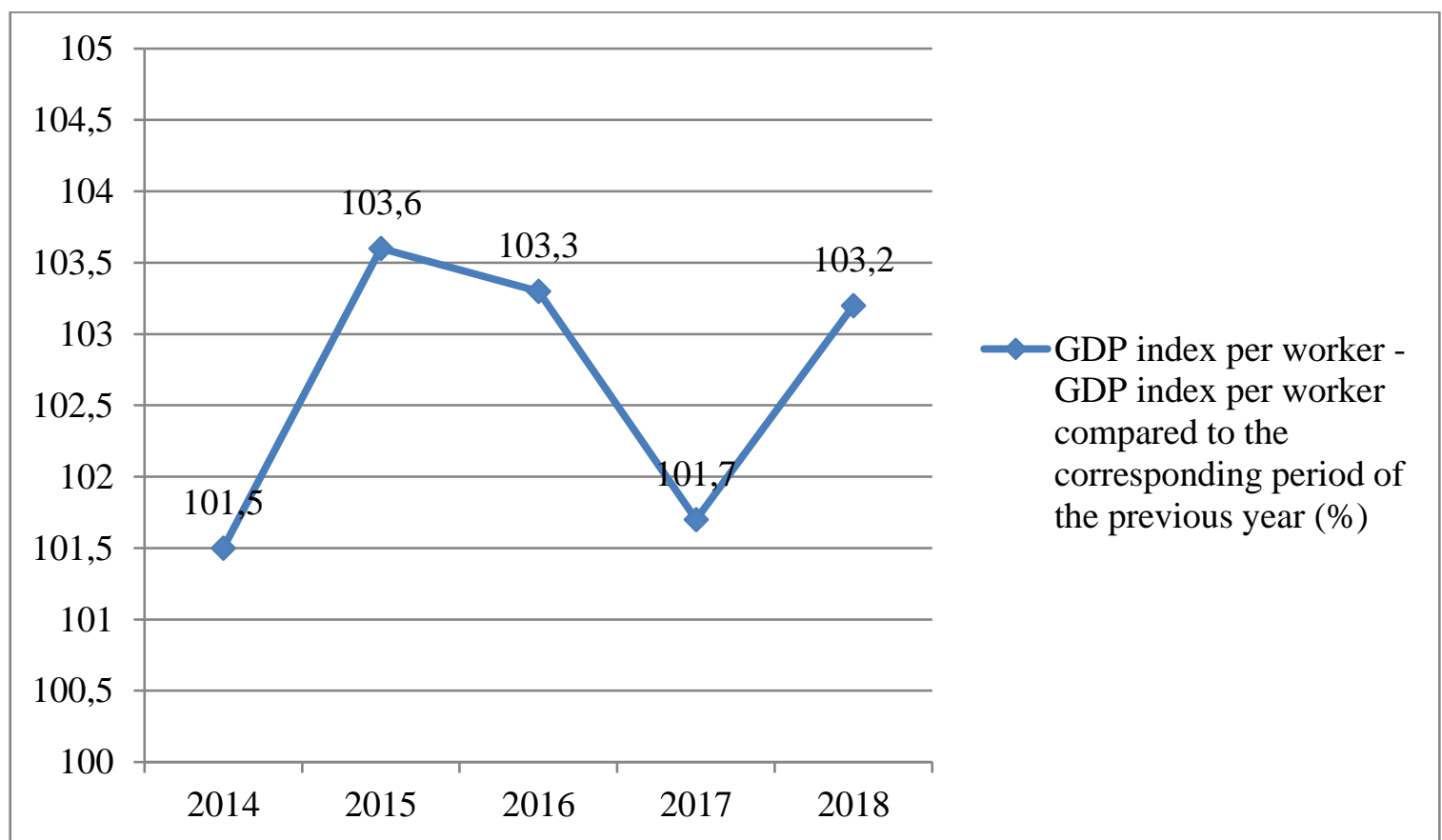

Figure 11 Labour productivity in Bulgaria for the period 2014-2018 (Source: Infostat, 2014-2018)

Disclosed in Figure 11 is the labour productivity dynamics in Bulgaria for the examined 5 years. This dynamics is characterised by periods of increase and decrease in productivity and there is no clearly expressed trend. For 2018 the GDP index per worker compared to 2014 has increased by $1.7 \%$, and compared to the previous year - by $1.5 \%$.

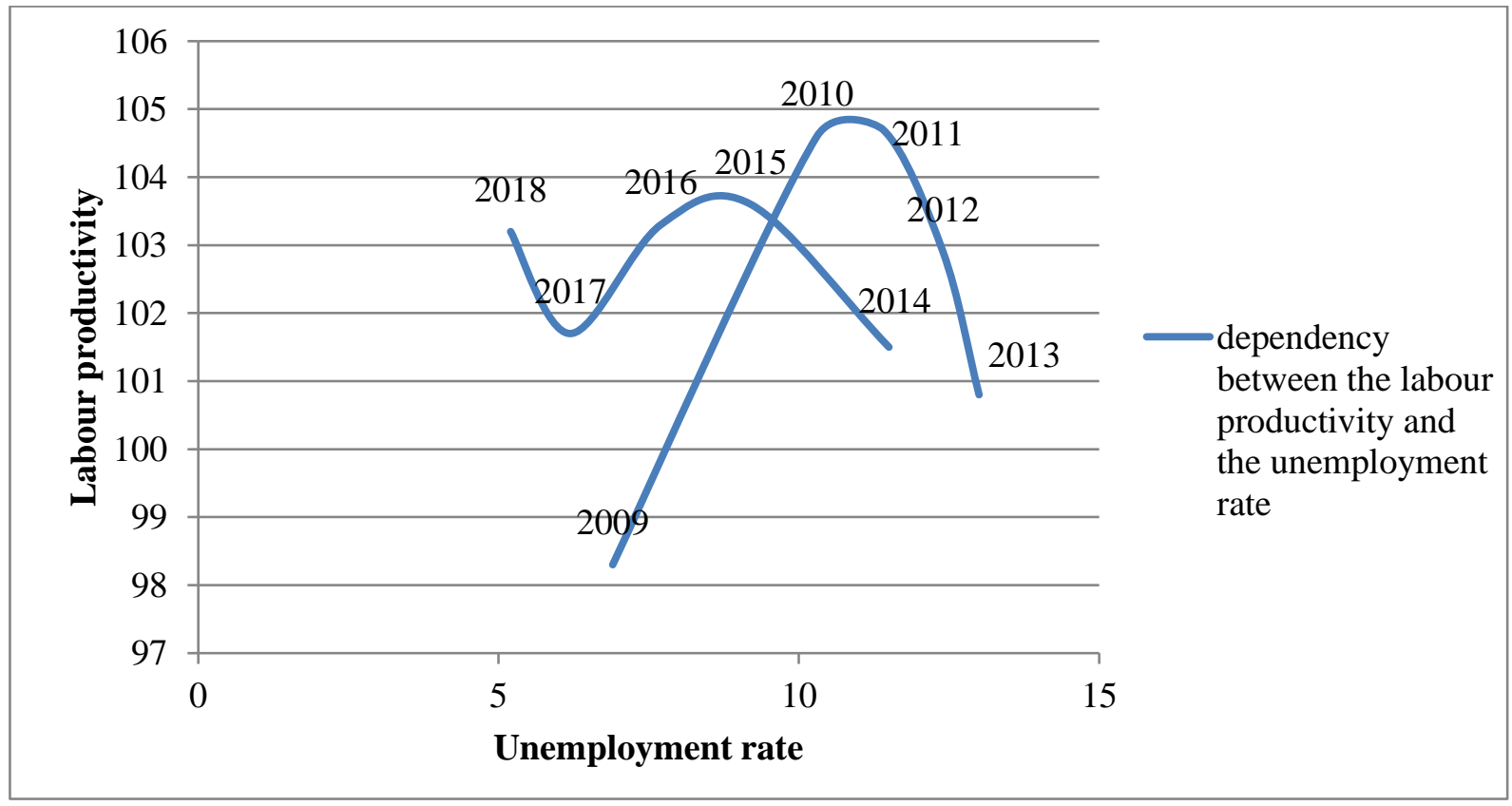


Figure 12 Relation between the labour productivity and the unemployment in Bulgaria (Source: Infostat,

2009-2018)

Displayed in Figure 12 is the dependency between the labour productivity and the unemployment rate for two periods - 2009-2013 and 2014-2018. At the start of 2009-2013 period, the levels of the GDP index per an employed individual and the unemployment rate were lower, as compared to the indices of the previous year. The unemployment rate peak of $12,9 \%$ was reached in 2013 , bringing out the dependency between the two indexes. In the examined period 2009-2013 there is a positive relationship between the two indexes and the correlation coefficient between them is positive: +0.52 . In the beginning of the next examined period a negative dependency is notices between these two indexes. With an increase in the labour productivity index a decrease in the unemployment rate is observed. This trend is generally preserved throughout the entire 2014-2018period. A reverse dependency is observed between the unemployment and the labour productivity - high labour productivity levels - decrease in unemployment and vice versa, which determines the negative correlation between them: -0.29 .

\subsection{Salary level}

The labour is one of the most important components of the economy and the expenses related to it, concern both employees and employers. For the employees the salaries in most cases are the main source of income, which determines their living standard and lifestyle, and this makes the salary a determining factor for the employee's welfare. The gross salary of a person includes the basic and the additional labour remuneration, including the taxes and the social security contributions due by the employee, but does not include the social security contributions at the expense of the employer. For the employers the labour expenses include direct expenses (expenses for basic and additional labour remunerations) and indirect expenses (expenses for social security of the employees). For example, with a gross salary of 1 000 BGN in 2019 after deducting the taxes due and the social security contributions at the expense of the employee, the net (clear) salary amounts to 775.98 BGN. The expenses for the employer, however, are $1190.20 \mathrm{BGN}$, because according to the law the employer is obliged to pay part of the employee's social security contributions at its own expense (Infostat). The taxes, which are mainly related to the labour, are the total income tax (a personal income tax), taxes on consumption and taxes on salary. (Мавров, 2007)

The personal income tax (PIT) regulates the taxation of the income of the physical persons, including income generated by the activities as a sole trader. The subject of taxation according to the Personal Income Tax Act are the incomes of the local and foreign physical persons. In Bulgaria, the so called flat tax is used for the personal income tax, which represents a tax system with a constant tax rate, i.e. a system, in which all participants in a given group (individuals or companies) are charged with the one and the same tax rate - a percentage of the income (in Bulgaria it is 10\%).

There is a relation between the level of the taxes and the unemployment level in a given country. The taxes on the labour income influence the employee's choice to work or not, but also influence the employer's choice regarding hiring employees, because if the income taxation level is higher it generally increases the labour expenses, too. The unemployment compensations also have impact on the employees' decisions. As a whole, reducing the labour income tax may be a tool to encourage higher employment levels. (European Semester)

\section{CONCLUSION}

The data, provided herein for the analysis of different factors, influencing the unemployment level in Bulgaria for the period 2014-2018, presented in a model of the Beveridge curve for the same period, gives us a reason to draw the following conclusions:

Globally, throughout the analysed period, the Beveridge model shows a steady trend of decrease in the unemployment rate in Bulgaria, which is an indicator of the fact that during that period there was an ascending economic development. i.e. observed was an economic growth; 
- The active labour market policy, applied during the analysed period, can be assessed as effective, as a whole. On the basis of this assessment we can conclude that the same policy may continue to be implemented in future, with no significant changes;

- The mutual relationship between the labour productivity and the unemployment level in the country concerning the analysed period shows different trends in terms of the labour productivity and a relatively steady trend of reduction in the rate of unemployment. This is a sign of an insufficient effectiveness of the overall economic policy of the country during the period under survey and possible influence of other factors on the rate of unemployment;

- In general, the labour migration during the analysed period has a negative impact on the state of the labour resources in the country and as a result, on the labour market flexibility, as well. This negative impact is extremely powerful for certain regions of the country. In this sense, taking measures to regulate the labour migration is of extreme importance.

\section{REFERENCES}

Андреева, 3. (2014). Характеристики на пазара на труда в България. В О. Хижов, (ред.). Пазар на труда в страните от Централна и Югоизточна Европа - преглед и перспективи. (стр. 37-46). Институт за икономическа политика. http://www.epibg.org/images/publications/bg_labour_market_trends_in_bulgaria_and_cee_region.pdf

Атанасова, М. \& Владимирова, К. (2011). Предизвикателствата пред политиките за заетост исоциална кохезия. В проф. К. Владимирова (ред.) Национални измерения на политиките на ЕС за развитие и заетост. Новите предизвикателства, свързани със заетостта и пазарите на труда, (стр. 100-128). Сиела.

Дончева, М. (2009). Пазар на труда: Макроикономически анализ. УИ “Пайсий Хилендарски”.

Дулевски, Л. (2010). Пазар на труда. Сиела.

Народно събрание на Република България (2018) Закон за републиканския бюджет на Република България за 2018. Държавен вестник, бр.99, Декември 12, 2018. Law on the State Budget of the Republic of Bulgaria for 2018 (published in the State Gazette, No. 99 since December 12, 2017)

Мавров, Х. (2007). Макроикономически зависимости на безработииата в България (теоритични аспекти и емпирично проявление в България). ИК Стено.

Петров, Т. (2014). Наръчник по социална политика. ТУ-Варна.

Ракаджийска, Т. (2010). Пазар на труда. ИУ-Варна.

Тодоров, Т. (2012). Подходи за изследване на заетостта и безработицата в България. ИК Шанс

Владимирова, К. (1995). На пазара на труда в България. ИК УНСС

\section{Online sources}

Employment Promotion Act. http://euroguidance.hrdc.bg/wp-content/uploads/2018/03/ZAKON-ZANASARChAVANE-NA-ZAETOSTTA_34.pdf

European Semester - Thematic Information Paper. Active employment policies. https://ec.europa.eu/info/sites/info/files/file_import/european-semester_thematicfactsheet_active-labour-market-policies_bg.pdf 
European Semester - Thematic Information Paper. Taxation. https://ec.europa.eu/info/sites/info/files/file_import/european-semester_thematicfactsheet_taxation_bg_0.pdf

Eurostat. A brief overview of the labor market.

https://ec.europa.eu/eures/printLMIText.jsp?ImiLang=bg\&regionId=BG0\&catId=9366

Infograph. Inactive persons. https://www.infograf.bg/dictionary/76

Infograph. Job vacancy rate. https://www.infograf.bg/dictionary/67

INFOSTAT Information System of the National Statistical Institute, Beveridge Curve . https://www.infograf.bg/dictionary/35

National Statistical Institute. Jobs and job vacancy rate - national level. https://www.nsi.bg/bg/content/15332/\%D0\%BC\%D0\%B5\%D1\%82\%D0\%B0\%D0\%B4\%D0 $\% \mathrm{~B} 0 \% \mathrm{D} 0 \% \mathrm{BD} \% \mathrm{D} 0 \% \mathrm{BD} \% \mathrm{D} 0 \% \mathrm{~B} 8 / \% 3 \mathrm{~F}-$ $\% \mathrm{D} 0 \% \mathrm{~B} 0 \% \mathrm{D} 0 \% \mathrm{~B} 1 \% \mathrm{D} 0 \% \mathrm{BE} \% \mathrm{D} 1 \% 82 \% \mathrm{D} 0 \% \mathrm{BD} \% \mathrm{D} 0 \% \mathrm{~B} 8-$ \%D0\%BC\%D0\%B5\%D1\%81\%D1\%82\%D0\%B0-\%D0\%B8\%D0\%BA\%D0\%BE\%D0\%B5\%D1\%84\%D0\%B8\%D1\%86\%D0\%B8\%D0\%B5\%D0\%BD\% D1\%82-\%D0\%BD\%D0\%B0-

\%D1\%81\%D0\%B2\%D0\%BE\%D0\%B1\%D0\%BE\%D0\%B4\%D0\%BD\%D0\%B8\%D1\%82\% D0\%B5-\%D1\%80\%D0\%B0\%D0\%B1\%D0\%BE\%D1\%82\%D0\%BD\%D0\%B8\%D0\%BC\%D0\%B5\%D1\%81\%D1\%82\%D0\%B0-\%E2\%80\%93\%D0\%BD\%D0\%B0\%D1\%86\%D0\%B8\%D0\%BE\%D0\%BD\%D0\%B0\%D0\%BB\%D0\%BD $\% \mathrm{D} 0 \% \mathrm{BE}-\% \mathrm{D} 0 \% \mathrm{BD} \% \mathrm{D} 0 \% \mathrm{~B} 8 \% \mathrm{D} 0 \% \mathrm{~B} 2 \% \mathrm{D} 0 \% \mathrm{BE}$

Report on the Report on the Implementation of the State Budget of the Republic of Bulgaria for 2018. https://www.minfin.bg/bg/1231

Statistical directory 2019. Sofia (p.46) https://www.nsi.bg/sites/default/files/files/publications/StatBook2019.pdf

Wikipedia. Beveridge Curve. https://en.wikipedia.org/wiki/Beveridge_curve 